\title{
The Effectiveness Of Product Placement By Media Types: Impact Of Image And Intention To Purchase
}

\author{
Frank Guennemann, Hawaii Pacific University, USA \\ Yoon C. Cho, KDI School of Public Policy and Management, Korea
}

\begin{abstract}
Product placement, as an integrated marketing communication tool, is widely applied to increase attention, interest, and purchasing intention. Product placement is also identified as an integrative conceptual model that captures how such messages generate audience outcomes (Balasubramanian, Karrah, and Patwardhan, 2006). By considering various applications of product placement in the automobile brands, the purpose of this study is to measure awareness, familiarity, image, and purchase intention of brands placed in various media types. In particular, this study measures 1) how brand awareness from product placement affects brand image, 2) how brand familiarity from product placement affects brand image, 3) how brand image affects purchase intention, and 4) the effects of brand awareness and familiarity based on different media types. This study applied a survey to collect data and used quantitative analyses to test hypotheses. The study provides managerial implications for the effectiveness of product placements by media types.
\end{abstract}

Keywords: Product Placement; Media; Brand Awareness; Familiarity; Image; Purchase Intention

\section{INTRODUCTION}

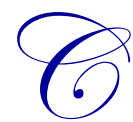

onventionally applied marketing communication tools to deliver messages, such as TV, radio, and print, have received more attention due to the development of newly applied media tools such as electronic and mobile environments. Marketing communication tools have been developed in various environments, such as online vs. offline environments (also called virtual/marketspace vs. non-virtual/marketplace), and in various forms such as direct vs. indirect forms. Among those tools, product placement is stated as an indirect and a prominent example of hybrid messages or paid attempts to influence audiences that do not identify the sponsor (Balasubramanian, 1994). Product placement, also often referred to as brand placement, can be defined as a "paid product message aimed at influencing movie (or television) audiences via the planned and unobtrusive entry of a branded product into a movie (or television program)" (Balasubramanian, 1994, cited in Karrh, 1998). Karrh (1998) stated that marketers have to look for ways to better reach their audience more effectively, one of them being product placement, which can be defined as "inclusion of branded products or brand identifiers, through audio and/or visual means, within mass media programming". Product placement is applied to reach a target audience effectively through traditional marketing means like advertising, due to a changing environment in which consumers show an increasing dislike of overt and obtrusive advertising through active and passive avoidance. In addition, new technological improvements, such as digital video recorders (DVRs), allow for easy skipping of television commercials (Lawrence, 1989; Olney, Holbrook, and Batra, 1991; Alwitt and Prabhaker, 1994; Zazza, 2002). Gupta and Gould (1997) indicated that placements do not necessarily have to be paid for in hard dollar terms by the marketer, but instead can include cross-promotions and mutually beneficial marketing campaigns, or simple, unpaid product or brand inclusions. Studies also mentioned that product placement is not restricted to movies and television programs but has recently extended to other media such as radio programs and game shows, print media (LaReau, 2005), and computer games (Schneider and Cornwell, 2005). Previous studies suggested that placement activities may target movies or television programs (Balasubramanian, 1994) and may yield real placements (i.e., those 
created as an integral part of movie production, often requiring the participation of movie actors/actresses) or virtual placements (i.e., those inserted via digital technology using a process independent from the production of the audiovisual segment (Gupta, Balasubramanian, and Klassen, 2000) that are widely applied with the technology enhancement.

Gupta, Balasubramanian, and Klassen (2000) stated that an increasing number of brand name products are vying for prominent positions within Hollywood movies. Previous studies indicated that Hollywood was receptive to attempts at influence by cigarette firms in the 1920s, with the result that actors and actresses smoked cigarettes in movies (Schudson, 1984, cited in Balasubramanian, 1994). As of today, there are a number of research papers and studies that deal with the effectiveness of product placement, most of which, however, focus on general consumer goods like soft drinks, food brands, or electronics (Gupta, Balasubramanian, and Klassen, 2000; Russell, 2002; Gupta and Lord, 1998; Schneider and Cornwell, 2005). Studies have shown that the practice of product placement was widely recognized and revived through the tremendous success of Reese's Pieces candy in the 1982 hit-movie E.T., which led to sales increases of 66 percent shortly after the release of the movie (Gupta and Lord, 1998; Gupta, Balasubramanian, and Klassen, 2000; Karrh, McKee, and Pardun, 2003). Since then, a myriad of products and brands have been shown and placed in movies, TV programs and other media; however, as far as the automobile industry is concerned, BMW's placement of its Z3 roadster in the 1995 blockbuster James Bond: GoldenEye was the starting point for the industry, which made the Z3 the company's most recognized car in its history (Spiegel Online, 2004). Likewise, after featuring its products in the next James Bond movie Tomorrow Never Dies in 1997, BMW's new motorcycle, the R1200c, became the best-selling motorcycle in 1998 (Castelligasse, 2005). BMW also placed a whole mini fleet of the MiniCooper in 2003's movie The Italian Job, which resulted in the company being unable to meet the great demand for the car (Castelligasse, 2005). By applying product placement as a media strategy tool, BMW gained over $\$ 100$ million in audience exposure value because of products such as the Z3 car and the 750iLs (Stewart-Allen, 1999, cited in Gupta, Balasubramanian, and Klassen, 2000). This also seems to be the case at Cadillac, which has increased the number of placements quite aggressively over the last few years, with 2003 being its busiest movie product placement year, as its cars appeared in eleven movies; namely, 2 Fast 2 Furious, Bad Boys 2, Bringing Down the House, Bruce Almighty, Cradle 2 the Grave, Dickie Roberts: Former Child Star, Kangaroo Jack, Phone Booth, Scary Movie 3, Terminator 3: Rise of the Machines, and The Matrix Reloaded (BrandChannel, 2005). The appearance of various automobile brands in television programs has hiked dramatically during the last few years, with an increase of 49 percent for the first six months of 2005 alone, compared to the whole of 2004 (Edwards, 2005). It was estimated that the value of this exposure would total about $\$ 784$ million (Edwards, 2005).

Previous studies have suggested that the main reason for the increase in use of product placement is an "oversaturated and fragmented advertising landscape" (Russell, 2002), in which it has become far more difficult for the marketer's message to reach the target audience. Suggested factors include active avoidance of TV advertisements by zapping away (Olney, Holbrook, and Batra, 1991), passive avoidance of (i.e., not paying attention to) TV advertisements, fragmentation of TV audiences, and TV clutter (Lawrence, 1989), as well as increasing dislike of TV advertising (Alwitt and Prabhaker, 1994). In addition, a relatively new threat to traditional advertising is the development and rapid penetration of digital video recorders or DVRs - also referred to as personal video recorders or PVRs, a relatively new medium that digitally records TV programs and lets viewers skip the commercials (Mack, 2004). By considering the development of reviewing systems, including DVR, TiVo, and Internet downloads, chances to skip advertising will be increased while product placements are more likely to be remembered. It is also questionable whether companies like DaimlerChrysler will keep spending $\$ 850$ million on TV ads (Mack, 2004), considering that DVR users skip commercials up to 72.3 percent of the time but recall product placements four times as much (Zazza, 2002). Hence, the application of product placement has received more attention among marketers, as have diverse media tools.

Although the automobile industry is a major player in strategic product placement, both in dollar terms and occurrence (Edwards, 2005), there is little research as to how effective the practice is for automobile brands, in particular, and whether it has any impact on consumer behavior (Mowen and Minor, 2000).

Based on this consideration, the purpose of this study is to investigate how consumers perceive product placement for automobile brands and how it affects their purchase decisions. This study also measures different 
impacts based on types of media. The research questions are: 1) How does customers' awareness of product placement of automobile brands affect the brand image?, 2) How does familiarity of product placement of automobile brands affect the brand image?, 3) How does the brand image affect purchase intention?, and 4) how doe the effects of brand awareness and familiarity of image differ based on media tools such as movie, TV program, print, and video game?

\section{LITERATURE REVIEW}

The effect of product placement, the use of a product's name, packaging, signage, or other trademarks in the media (Steortz, 1987, cited in Nelson and Deshpande, 2013), and as part of marketing communication tools on attitudes to products or brands, has been widely investigated. Belch and Belch (2004) stated that product placement is most efficient if it is part of an integrated marketing communication approach; i.e., the strategic integration and coordination of the various communications functions instead of having them operate separately, thereby avoiding duplication, taking advantage of the synergy effect, and developing more efficient and effective marketing communications programs. Gillespie, Joireman, and Muehling (2012) stated that the bulk of past research on product placement has explored how features of the placement impact recognition of and attitudes toward brands and products (Balasubramanian, Karrh, and Patwardhan, 2006; Karrh, 1998). Previous studies explored normative influence on product placement effects (Noguti and Russell 2014), the effect of prominence and mode on audience recall (Gupta and Lord, 1998), consumers' perceptions of ethics and acceptability (Gupta and Gould, 1997), issues of paid and unpaid product placement (Hackley and Tiwsakul, 2012), brand placement, brand recall and choice in entertainment media (Hang, 2014), consumer socialization (Gregorio and Sung, 2010), and consumer response to foreign and domestic brand placement (Nelson and Deshpande, 2013).

Product placement can also be called brand placement depending on whether product or brand is highlighted (Karrh, 1998). The inclusion of branded products or identifiers through audio or visual means within mass media programming can also be called brand integration (Balasubramanian, 1994, cited in Wiles and Danielova, 2009). Product placement has shifted closer to the realm of conventional marketing as customers have become more marketing savvy and the technique has become more prominent; it originally fell under the umbrella of covert marketing (Karniouchina, Uslay, and Erenburg, 2011). Product placement is applied with similar beliefs to advertising, such as increased awareness, increased interest, increased intention to purchase, and changed behavior, but with different perspectives. Among the applications of product placement in different types of media, various studies have explored the effects of product and brand placement in movies. Studies have examined the effects of product placement in a cultural context (Nelson and Deshpande, 2013), the economic growth of product placement in movies (Karniouchina, Uslay, and Erenburg, 2011), and placement modality, character associations, and blatancy (Wiles and Danielova, 2009). Other studies have measured the effects of product placement in television programs (Gillespie, Joireman, and Muehling, 2012; Hackley and Tiwsakul, 2012) and video-game advertisements (Hang, 2014). Previous studies have explored the effects on consumers of product placements (Auty and Lewis, 2004; Russell 2002, cited in Noguti and Russell, 2014) by addressing ignorance of the social environment of television series consumption. It is also being argued that nowadays the level of effectiveness of traditional marketing efforts, like advertising - on TV, on radio, or in print media - is constantly decreasing due to environmental changes, such as consumers increasing dislike of overt advertising or the rapid penetration of DVRs, allowing consumers simply to skip the ads broadcast on TV (Lawrence, 1989; Alwitt and Prabhaker, 1994; Zazza, 2002; Mack, 2004). Hence, there seem to be good reasons for marketers to believe in product placement being able to deliver persuasive messages to the consumer. Various studies have addressed the effectiveness of product placement, such as recognition (Brennan and Babin, 2004), recall, and attitudes (Gupta and Gould, 1997).

Theoretically, the theory of reasoned action (TRA), which discusses a person's beliefs about the nature of anticipated outcomes, influences the formation of attitudes that influence behavioral intentions (Ajzen and Fishbein, 1980). Encoding variability theory; i.e., repeating a theme with small variations, can enhance the audience's memory of the theme (Singh, Mishra, Bendapudi, and Linville, 1994) and support learning through repetition of product placement. Increasing media exposure influences consumers' attitudes and behaviors through product placement (Johnstone and Dodd, 2000). 
Brand awareness deals with depth - brand recognition and recall - and breadth - purchase and usage of a product. Brand image affects customers' associations with a brand, which preferably should be strong (relevance and consistency), favorable (desirability and deliverability), and unique (points-of-parity and points-of-difference) (Keller, 2008). Brand attitudes ultimately decide the outcomes, which in the most preferable situation, are brand loyalty, less vulnerability to crises and competitor actions, larger margins, more elasticity to price decreases (gaining more customers) and more inelasticity to price increases (losing fewer customers), improved perceptions of product performance, brand extensions opportunities, greater trade cooperation (value chain), licensing opportunities, and increased marketing communication effectiveness and efficiency (Keller, 2008). The Associative Network Memory Model, which deals with a process called spreading activation, is a model for understanding how product placement works (Anderson, 1983; Wyer and Srull, 1989). In this regard, recall refers to the process by which an individual reconstructs the stimulus itself from memory, while recognition requires the differentiation or discrimination of a stimulus from other stimuli (Johnstone and Dodd, 2000). Here, memory is viewed as a network of nodes and connecting links, nodes being stored pieces of information and links being the associations between one piece of information and another, making it possible to store any type of information in the memory network that is verbal, visual abstract, or contextual in nature (Keller, 2008). Related to this is a study by Janiszewski, Noel, and Sawyer (2003), which focused on the relationship between advertising repetition and consumer memory, suggesting that "understanding how different types of repeated ad material are learned and remembered can provide insight into how to make advertising more effective" (Janiszewski, Noel, and Sawyer, 2003). They found that a most effective communication strategy is one that combines "spaced exposures" alternating between more involving media, like television commercials, and less involving media, like product placement (Janiszewski, Noel, and Sawyer, 2003). Thus, it seems that a repetition of advertisements, in combination with strategic product placement, will create a mnemonic cue in the mind of the consumer, which will lead to a top-of-mind awareness of the brand (Belch and Belch, 2004). Furthermore, increasing media exposure influences increasing potential for (unrecognized) observational learning from the media; i.e., the (unrecognized) subconscious influence of consumers through product placement (Johnstone and Dodd, 2000). Thus, consumers learn by observing the protagonist's 'model' behaviors leading to desirable results, thereby 'experiencing' the product or brand featured in a movie, TV program, or video game (Balasubramanian, 1994). For instance, Matthew McConaughey's character - Brandon Lane getting a Mercedes SL600 to underline his new job position in the movie Two for the Money - can function as a mnemonic cue which, if congruent with the consumer's self-image, can inform and reinforce the social status of a consumer who aspires for such prestige (Markin, 1979).

While there has been much research on the effectiveness of product placement in general, this study focuses on automobile brands, where there has been barely any research undertaken so far. Balasubramanian (1994) argues that the effectiveness of product placement could be somewhat diluted if the consumer believes the endorser (here, the movie maker) had mostly been economically motivated in placing the product - considering plot incongruence (Balasubramanian, 1994; Russell, 2002). Moreover, the consumer can be conditioned through a product's or brand's repeated association with a highly regarded celebrity or persona, e.g. Pierce Brosnan's hero character James Bond driving a BMW 750iL leading to a desired consumer response, like deeper involvement with the brand (Balasubramanian, 1994). There seems to be empirical evidence that product placement can be a valuable tool for automobile brands; for instance, BMW created brand equity of $€ 184$ million ( $\$ 222$ million) value by featuring its Z3 roadster in the James Bond movie GoldenEye, making it the most-renowned car in the company's history (Spiegel Online, 2004), and creating more than $\$ 100$ million brand equity value by featuring the 750iL sedan and R1200c motorcycle in Tomorrow Never Dies (Stewart-Allen, 1999), making the R1200c the best-selling motorcycle in 1998 (Castelligasse, 2005).

\section{HYPOTHESES DEVELOPMENT}

\section{Effects Of Brand Awareness On Image}

Brand awareness that significantly impacts consumer decision-making (Huang and Sarigollu, 2012) occurs when consumers can recall or recognize a brand or simply when consumers know about a brand (Keller, 2008; Huang and Sarigollu, 2012). Brand awareness may signal presence and substance, because of high awareness for a long time, because the firm's products are widely distributed, and because the products associated with the brand are purchased by many other buyers (Aaker, 1991; Hoyer and Brown, 1990; also cited in Homburg, Klarmann, and 
Schmitt, 2010). Many researchers (Gupta and Lord, 1998; Gupta, Balasubramanian, and Klassen, 2000; Johnstone and Dodd, 2000; Russell, 2002) believe that placing products and brands in various media, such as movies, television programs, print, or video games, can have a significant impact on consumers' brand knowledge structure; i.e., brand awareness and brand image (Keller, 2008). In this regard, prominent and highly visible placements of cars can be an important factor in creating awareness and image for a certain brand, especially when the placement conveys performance, realism, plot congruence, and social status perceptions (Balasubramanian, 1994; Markin, 1979; Russell, 2002). Product placement and other marketing programs and brand elements (e.g. brand name, logo, slogan, etc.) were applied to generate associations (about the company, country of origin, etc.) to develop brand awareness and brand image (Keller, 2008). DeLorme and Reid (1999) found that product placement in movies was most effective when the audience had a positive perception of plot/scenery congruence, a prior consumption experience, an empathy with characters portrayed and an involvement with the story, and awareness of traditional advertising for the brand featured in the movie. Johnstone and Dodd (2000) found that, within a controlled environment in the theater, product placement has the potential to increase brand salience, dependent, however, on the type, length, and context of the placement. Russell (2002) investigated the effectiveness of product placement in television programs with regard to modality and plot connection congruity and its effect on memory. Among diverse applications on various media types, which media is most effective and how customers perceive it is less examined. Based on this consideration, this study examines how customers' awareness through placements that are associated with cues, such as characters or product features, affect brand image. Therefore, this study also hypothesized that the effects of brand awareness on image are based on media types.

H1a: Brand awareness of automobile brands from product placement in movies affects an enhanced brand image.

H1b: Brand awareness from product placement in TV programs affects an enhanced brand image.

H1c: Brand awareness from product placement in print media affects an enhanced brand image.

H1d: Brand awareness from product placement in video games affects an enhanced brand image.

\section{Effects Of Brand Familiarity On Image}

Brand familiarity is defined as a unidimensional construct that is directly related to the amount of time that has been spent processing information about the brand, regardless of the type of content of the processing that was involved (Baker, Hutchinson, Moore, and Nedungadi, 1986). It is also defined as the number of productrelated/service-related experiences that have been accumulated by the consumer (Alba and Hutchison, 1987, also cited in Tam, 2008). Previous studies have stated that familiar brands tend to exhibit stronger associations with product categories (Lee and Sternthal, 1999; Negunadi 1990) making them more accessible in memory (Negunadi, 1990, cited in Brennan and Babin, 2004). Previous studies have examined the effect of brand familiarity on the attitude toward an ad-brand attitude relationship (Phelps and Thorson, 1991), with experience contributing to brand familiarity (Johnson and Kellaris, 1988), and the evoked set (Baker, Hutchinson, Moore, and Nedungadi, 1986), the effects of the brand familiarity on response to stimuli (Anand and Sternthal, 1990, also cited in Stammerjohan, Wood, Chang, and Thorson, 2005), and its effects on satisfaction evaluations (Tam, 2008). Dahlen and Lange (2004) suggested that brand familiarity is a very powerful factor in advertising. Brennan and Babin (2004) discussed brand familiarity and placement recognition (Babin and Carder, 1996; Brennan, Dubas, and Babin, 1999). Based on this consideration, this study hypothesized that brand familiarity, due to product placement, affects image. This study also hypothesized the effects of familiarity on image based on media types.

H2a: Brand familiarity from product placement in movies affects an enhanced brand image.

H2b: Brand familiarity from product placement in TV programs affects an enhanced brand image.

H2c: Brand familiarity from product placement in print media affects an enhanced brand image.

H2d: Brand familiarity from product placement in video games affects an enhanced brand image. 


\section{Effects Of Brand Image On Purchase Intention}

Brand image refers to consumer perceptions and encompasses a set of beliefs that consumers have about the brand (Srivastava and Kamdar, 2009). Shah, Aziz, Jaffari, Waris, and Ejaz (2012) indicated that brands may impact purchase intention influencing a customer to purchase a particular brand. Purchase intention is defined as an individual's intention to buy a specific brand he or she has chosen for him or herself after a certain evaluation (Khan, Ghauri, and Majeed, 2012; Laroche, Kim, and Zhou, 1996). Customers' intention to purchase a focused brand is not merely caused by their attitude to the brand, but also by their attitudes to other brands they might otherwise have considered (Porter, 1974, cited in Shah, Aziz, Jaffari, Waris, and Ejaz, 2012). Previous studies have discussed the impacts of attitudes toward brand/product (Stammerjohan, Wood, Chang, and Thorson, 2005) and satisfaction and purchase intentions (Taylor and Baker, 1994; Cronin and Taylor, 1992). Based on this consideration, this study hypothesized the impact of brand image on purchase intention.

H3: Overall, brand image due to product placement positively affects purchase intention.

\section{METHODOLOGY}

This study measures the effectiveness of product placement for automobile brands and its effect on purchase intention. In particular, this study measures 1) how brand awareness of due to product placements improves brand image, 2) how brand familiarity due to product placement improves brand image, 3) how brand image arising from product placement affects purchase intention, and 4) how the effects of brand awareness and familiarity of image are different based on media types. A five-point Likert scale was applied for each construct (i.e., 1 is" strongly disagree" and 5 is "strongly agree"). Random data collection was applied.

The survey took about 15 minutes to complete and started out by briefly summarizing the research topic and explaining the concept of product placement, containing examples of the major media types movies, TV programs, print, and video games. The first section covered consumers' habits with regard to frequency of going to the movies (occasions per month), watching TV (hours per week), reading various print media (hours per week), and playing video games (hours per week). Section two of the survey contained a number of questions about consumers' perceptions of product placement in the various media, such as level of awareness, liking, or preferences. The third section contained a number of open-ended questions about consumers' awareness of car brands; i.e., the subjects were asked to list car brands they were aware of, which they have seen in movies, TV programs, print media, and video games, as well as car brands they have purchased in the past or are likely to purchase in the future and for which reasons. Section four was optional and contained demographics such as age, gender, nationality/ethnicity, educational status (undergraduate, full-time graduate, part-time graduate), and annual income level. In order to get valid data, the questionnaire was distributed to 290 subjects. Data analysis, such as ANOVA, regression and correlation analyses were applied for hypothesis testing.

\section{DATA ANALYSIS}

\section{Demographics}

A total of 290 surveys were distributed and 265 valid responses were collected. Thus, the response rate was 91.4 percent. Of the respondents, 54.7 percent were male and 42.7 percent were female. Respondents were between the ages of 18 and 43 years and 95.6 percent were in the target age group bracket of 18 to 35 years. The mean age was 25.6 years and the educational status was almost evenly distributed with 46.8 percent being undergraduate students and 49.1 percent graduate students. With regard to cultural diversity, out of the 265 respondents, 24.2 percent were U.S. American, 33.6 percent Asian, and 30.6 percent European. Also, 33.2 percent reported an annual income of $\$ 10,000$ to $\$ 30,000,9.8$ percent between $\$ 30,001$ and $\$ 50,000,5.7$ percent between $\$ 50,001$ and $\$ 70,000$, 3.8 percent between $\$ 70,001$ and $\$ 100,000$, and 2.6 percent more than $\$ 100,000$.

This study evaluated the respondents' frequency of watching or exposure to the different media types; i.e., how often they go to the movies per month, watch TV shows, read print media, and play video games. Results are: 63.8 percent of respondents attend the movies at least one to two times per month, 21.1 percent three to four times 
per month, and 9.4 percent never attend movies. With regard to TV frequency, 28.7 percent reported watching TV programs less than or equal to four hours per week, 34.0 percent between four and ten hours, 33.2 percent more than ten hours per week, and only 4.1 percent never watch TV programs, apparently making television shows a strong medium to reach the target audience. Looking at the frequency of reading print media per week, 52.5 percent spend less than or equal to four hours per week, 34.7 percent more than four to ten hours, 6.4 percent more than ten to 16 hours, 3.0 percent more than 16 hours, and 3.4 percent never read print media. With regards to the frequency of playing video games, while 30.2 percent reported spending less than or equal to four hours per week on them, a staggering 56.6 percent never play video games at all, apparently making it the least effective of all four media types to reach the automobile manufacturers' target audience. Respondents' awareness of certain automobile brands in the various media types shows that in movies, BMW - one of the heaviest users of product placement in the industry scored the highest level of awareness with 22.7 percent, followed by Mercedes (8.4 percent) and Audi (7.6 percent). However, 20.3 percent were not aware of any car brands in movies (Figure 1).

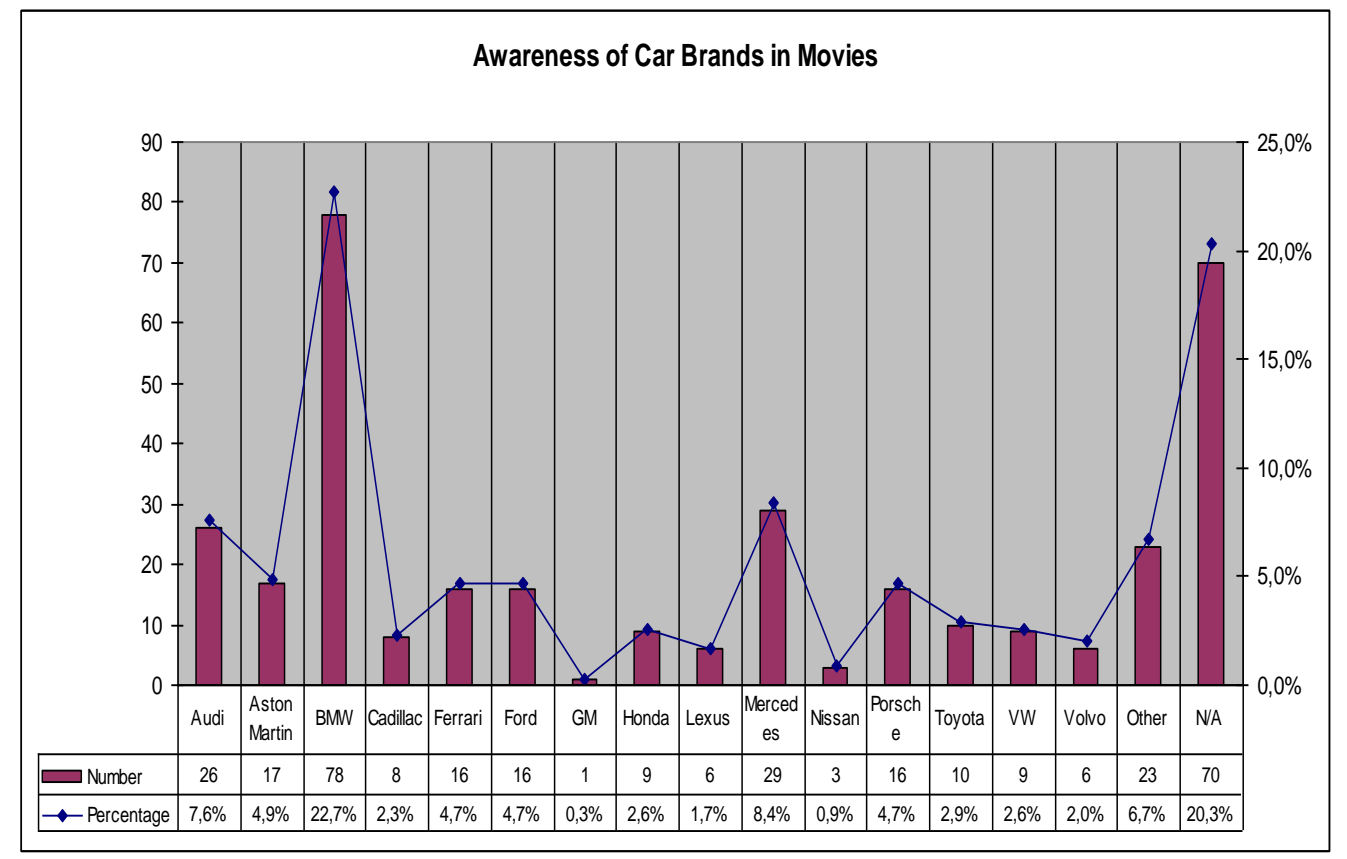

Figure 1: Awareness Of Automobile Brands In Movies

BMW also holds the number one position in TV programs (Figure 2) with 13.4 percent, this time, however, followed by Ford (9.1 percent), which ranks number one in both occurrence and duration in American television shows, and Mercedes (8.3 percent), while 21.7 percent of the respondents could not remember having seen any car brands on TV. 


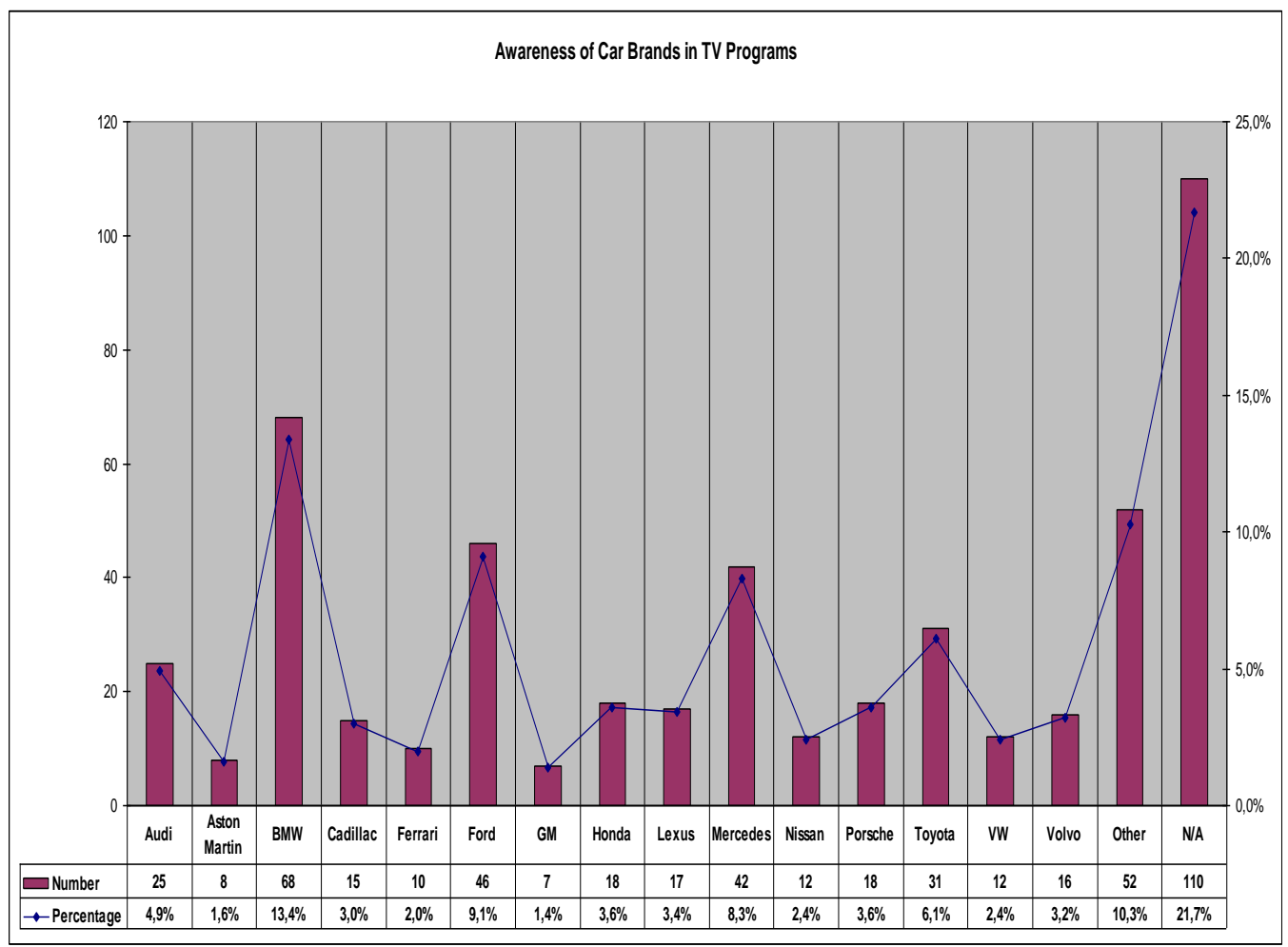

Figure 2: Awareness Of Automobile Brands In TV Programs

In print media (Figure 3), BMW again scores the highest value of all brands, this time, however, significantly lower with only 10.5 percent, followed by Mercedes ( 8.1 percent) and Ford ( 6.1 percent). The number of respondents unaware of car brands in this medium has risen to 30.4 percent.

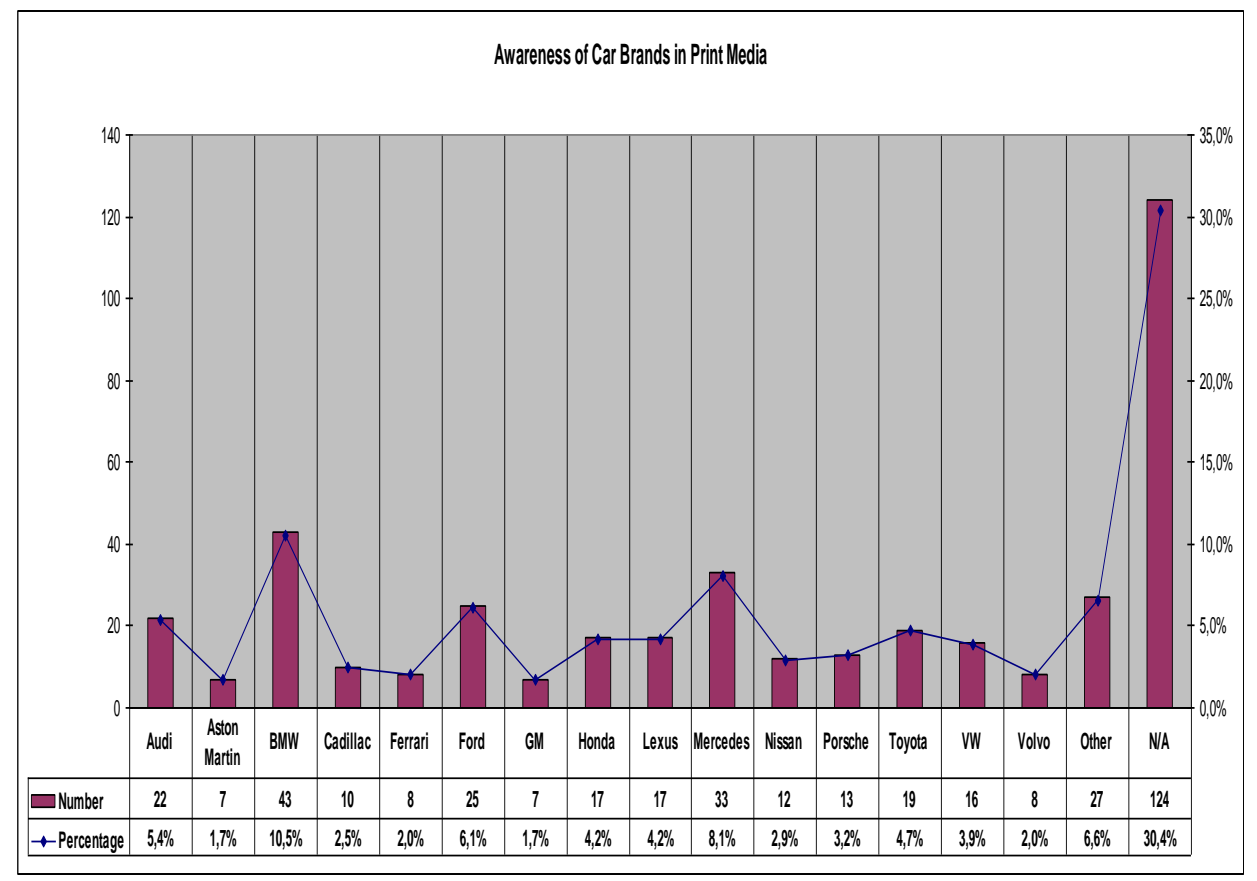

Figure 3: Awareness Of Automobile Brands In Print Media 
The level of awareness decreases even further in video games (Figure 4), where 38.0 percent are totally unaware of any car brands, while this time Honda is in the lead with 6.9 percent, followed by Ferrari (6.0 percent) and Ford (4.5 percent).

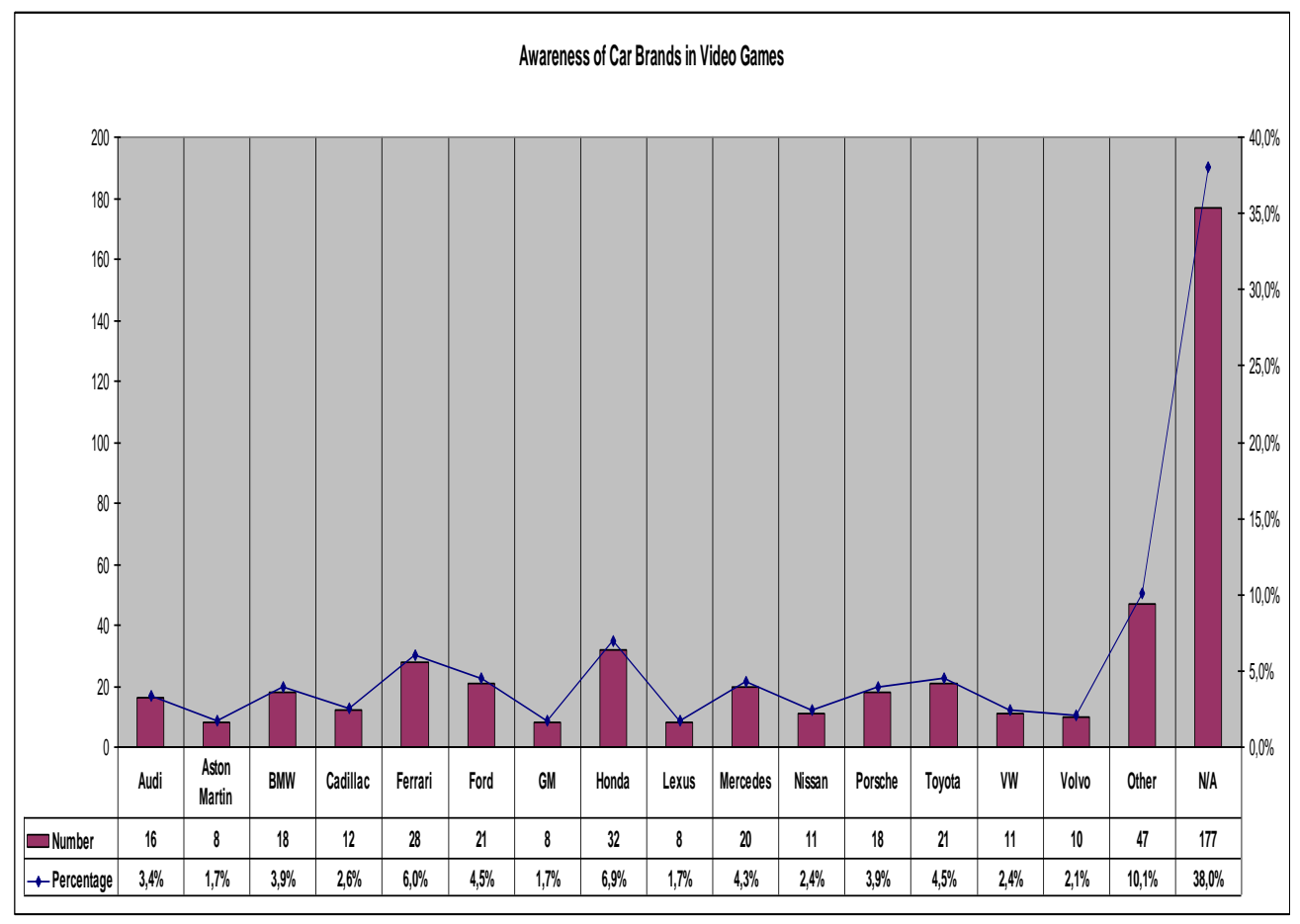

Figure 4: Awareness Of Automobile Brands In Video Games

\section{Hypothesis Testing}

To analyze the proposed hypotheses, this study applied the results from the quantitative analyses such as ANOVA and regression analyses. Table 1 provides the results of the regression analyses for the effects of brand awareness on image based on different types of media. The results of this study are that the effect of brand awareness on image is significant in the case of product placements in movies at the 0.05 level, while the effect of brand awareness on image in the case of other media types was not significant. Therefore, hypothesis 1a was accepted. Overall, the ANOVA on the effects of brand awareness on image based on different types of media found the models significant at the .01 level with $F=3.734$ ( $r$-square $=.154)$.

Table 1: Summary Of The Effects Of Brand Awareness On Image Based On Media Types

\begin{tabular}{|l|c|}
\hline Variable (Independent -> Dependent) & Standardized Coefficient $(\boldsymbol{t}$-value-Sig) \\
\hline Brand Awareness -> Image (Movie: H1a) & $0.209(2.422 * *)$ \\
\hline Brand Awareness -> Image (TV Program: H1b) & $0.100(1.182)$ \\
\hline Brand Awareness -> Image (Print Media: H1c) & $0.041(0.542)$ \\
\hline Brand Awareness -> Image (Video Games: H1d) & $0.114(1.619)$ \\
\hline
\end{tabular}

** Significant at 0.05 level (2-tailed).

Table 2 provides the results of the regression analyses for the effects of brand familiarity on image based on different types of media. The results of this study are that the effect of brand familiarity on image is significant in the case of product placements in movies at the 0.05 level, while effects of brand familiarity on image in the case of other media types were not significant. Therefore, hypothesis $2 \mathrm{a}$ was accepted. Overall, the ANOVA on the effects of brand familiarity on image based on different types of media found the models significant at the .01 level with $F$ $=4.084$ ( $r$-square $=.162)$. 
Table 2: Summary of the Effects of Brand Familiarity on Image based on Media Types

\begin{tabular}{|l|c|}
\hline Variable (Independent -> Dependent) & Standardized Coefficient (T-Value-Sig) \\
\hline Brand Familiarity -> Image (Movie: H2a) & $0.209\left(2.415^{* *}\right)$ \\
\hline Brand Familiarity -> Image (Tv Program: H2b) & $0.109(1.110)$ \\
\hline Brand Familiarity -> Image (Print Media: H2c) & $0.153\left(1.865^{*}\right)$ \\
\hline Brand Familiarity -> Image (Video Games: H2d) & $0.014(0.202)$ \\
\hline
\end{tabular}

** Significant at 0.05 level (2-tailed); * Significant at 0.1 level (2-tailed).

Further, this study measured the effects of overall brand image on purchase intention (H3: shown in Table 3 ). The results of the regression analysis were significant for the effects of brand image on purchase intention at alpha $=1 \%$. Therefore, Hypothesis 3 was accepted. Overall, the ANOVA on the effects of brand image on purchase intention found the models significant at the .01 level with $F=28.723(r$-square $=.198)$.

Table 3: Summary Of The Effects Of Brand Image On Purchase Intention

\begin{tabular}{|l|c|}
\hline Variable (Independent $->$ Dependent) & Standardized Coefficient (t -value-Sig) \\
\hline Brand Image -> Purchase Intention (H3) & $0.314\left(5.359^{* * *}\right)$ \\
\hline$* * *$ Significant at 0.01 level (2-tailed) & \\
\hline
\end{tabular}

\section{CONCLUSION}

This study measured the effects of brand awareness and familiarity due to placements on brand image and the effects of overall brand image on purchase intention. This study also measured the effects of brand awareness and familiarity on brand image based on different media types. The results of the study found that 1) the effects of both brand awareness and familiarity on brand image are significant in the case of movies, but not in the case of other media and 2) the effect of overall brand image on purchase intention is significant. Therefore, this study concludes that product placement affects consumers' perceptions about automobile brands in the case of placement in movies and overall brand image appears to affect purchase decision-making.

It should be noted that for the marketer's efforts to be successful in delivering messages that the target audience will understand and acknowledge, product placement can play a pivotal role in the case of movies, but not in the cases of other media tools, such as TV programs, print, and video games. Effects of automobile product placement in other media besides movies are not found significant as customers recall automobile product placement in movies more strongly than other media, such as TV, print, and video games. Product placements are increasingly finding their way into TV programs, but are qualitatively different from a movie theater (Gupta and Lord, 1998). Even though there are advantages of product placement in TV programs (e.g., diverse choices) other than in movies, product placement in TV programs had limitations, such as size of the screen and specific product categories (e.g., alcohol beverages and cigarettes). When placing an automobile brand in a major blockbuster movie airing around the world, this study suggests that it should be considered if this particular brand is available in those markets. For instance, from a management point of view, Cadillac's decision to spend millions of dollars on a number of prominent product placements (such as Be Cool, Matrix: Reloaded, among others) is questionable, when this brand is sold almost exclusively in the United States but is rarely available in any other markets where these movies are aired. A repetition of advertisements, in combination with strategic product placement, will create a mnemonic cue in the mind of the consumer, which - in a favorable case - will lead to a top-of-mind awareness of the brand (Belch and Belch, 2004). This might be the case of BMW, which was successful in creating a favorable image through a combination of prominent product placements, creating its own short movies (BMWFilms.com) and also a number of popular advertisements, all of which were consistent with the company's motto and theme of the ultimate driving machine. Likewise, as the results of this study show, placement, in particular in movies, increases the level of brand awareness, brand familiarity, brand image, and purchase intentions.

While this study makes both practical and academic contributions, there are some limitations to it. First, the study was conducted with a sample size of 265 subjects; a bigger sample size would possibly elicit more representative results. With regard to the selected media, although print media and video games are becoming increasingly popular targets for product placement (LaReau, 2005; Schneider and Cornwell, 2005), the inclusion of such dissimilar media into the study did not deliver optimally comprehensive results, since respondents tended to show little interest in video games (56.6 percent), showed significantly higher levels of unawareness of automobile 
brand placements, and seemed to confuse automobile brand placements in print media with articles about automobile brands in car magazines.

An extension of this research for future investigation could be a deeper and more exclusive insight into the various media, such as a stronger focus on product placement of automobile brands solely in television programs or solely in movies. Effects of other product categories and specific brands might be considered in future research. Regulations on product placement and public policy issues could be discussed in future research. Future research could also focus on the effectiveness of combining tools such as event promotions and advertising campaigns. Finally, future research could also focus on consumer response to product placement changing over time and cultural differences. Cause and effect analysis and qualitative research also could be used in further research.

\section{AUTHOR INFORMATION}

Frank Guennemann received his Master's degree from Hawaii Pacific University. E-mail: frankguennemann@gmx.de.

Professor Cho received her MBA from Cornell and Ph.D. in Management from Rutgers University. She was associate professor at Hawaii Pacific University and currently professor at the KDI School of Public Policy and Management, Seoul, Korea. She published research papers in the various academic journals such as Journal of Business Research (JBR), Advances in Consumer Research (ACR), Journal of Business \& Economics Research (JBER), etc.

E-mail: ycho@kdischool.ac.kr. (Corresponding author)

\section{REFERENCES}

1. $\quad$ Aaker, David A. (1991), Managing Brand Equity, New York: The Free Press.

2. Ajzen, Icek, and Fishbein, Martin (1980), Understanding Attitudes and Predicting Social Behavior, New Jersey: Prentice-Hall.

3. Alba, J.W. and Hutchinson, J.W. (1987), "Dimensions of Consumer Expertise," Journal of Consumer Research, 13, March, 411-54.

4. Alwitt, Linda and Prabhaker, Paul (1994), "Identifying Who Dislikes Television Advertising: Not by Demographics Alone," Journal of Advertising Research, 34(6), 17-29.

5. Anand, Punam and Sternthal, Brian (1990), "Ease of Message Processing as a Moderator of Repetition Effects in Advertising," Journal of Marketing Research, 27, August, 345-353.

6. Anderson, John (1983), The Architecture of Cognition. Cambridge, MA: Harvard University Press.

7. Auty, Susan and Lewis, Charlie (2004), "Exploring Children's Choice: The Reminder Effect of Product Placement," Psychology and Marketing, 21(9), 697-713.

8. Babin, Laurie A. and Carder, Sheri T. (1996), "Viewers' Recognition of Brands Placed Within a Film," International Journal of Advertising, 15(2), 140-151.

9. Baker, William, Hutchinson, J. Wesley, Moore, Danny, and Nedungadi, Prakash (1986), "Brand Familiarity and Advertising: Effects on the Evoked Set and Brand Preference," Advances in Consumer Research, Vol.13, eds. Richard J. Lutz, Provo, UT : Association for Consumer Research, 637-642.

10. Balasubramanian, Siva K. (1994), "Beyond Advertising and Publicity: Hybrid Messages and Public Policy Issues,” Journal of Advertising, 23(4), December, 29-46.

11. Balasubramanian, Siva K., Karrah, James A., and Patwardhan, Hemant (2006), "Audience Response to Product Placements," Journal of Advertising, 35(3), Fall, 115-141.

12. Belch, George and Belch, Michael (2004), Advertising and Promotion - An Integrated Marketing Communications Perspective, $6^{\text {th }}$ edition. New York, NY: McGraw-Hill/Erwin.

13. BMW Films (2005), Retrieved September $24^{\text {th }}, 2005$, from http://www.bmwfilms.com.

14. Brandchannel (2005). Retrieved November $11^{\text {th }}, 2005$, from http://www.brandchannel.com/brandcameo_brands.asp?brand_year=2005\&pageno=1\&bn_id\#1023.

15. Brennan, Ian and Babin, Laurie A. (2004), "Brand Placement Recognition: The Influence of Presentation Mode and Brand Familiarity," Journal of Promotion Management, 10(1), 185-202.

16. Brennan, Ian, Dubas, Khalid M., and Babin, Laurie A. (1999), “The Effects of Placement Type and 
Exposure Time on Product Placement Recognition," International Journal of Advertising, 18, 323-338.

17. Castelligasse (2005), "Product Placement". Retrieved September $14^{\text {th }}, 2005$, from http://www.castelligasse.at/Werbetechnik/Product-Placement/product-placement.htm.

18. Cronin, Joseph J. Jr. and Taylor, Steven A. (1992), "Measuring Service Quality: A Reexamination and Extension," Journal of Marketing, 56(3), July, 55-68.

19. Dahlen, Micael and Lange, Fredrik (2004), "To Challenge or Not To Challenge: Ad-Brand Incongruency and Brand Familiarity," Journal of Marketing Theory and Practice, Summer, 20-35.

20. DeLorme, Denise and Reid, Leonard (1999), "Moviegoers' Experiences and Interpretations of Brands in Films Revisited," Journal of Advertising, 28(2), 71-95.

21. Edwards, Jim (2005), "Car Marketers and Networks at Odds Over Heavy Traffic". Brandweek, 7/11/2005, 46(27).

22. Gillespie, Brian, Joireman, Jeff, and Muehling, Darrel D. (2012), “The Moderating Effect of Ego Depletion on Viewer Brand Recognition and Brand Attitudes following Exposure to Subtle Versus Blatant Product Placements in Television Programs," Journal of Advertising, 41(2), Summer, 55-65.

23. Gregorio, Federico de and Sung, Yongjun (2010), "Understanding Attitudes toward and Behaviors in Response to Product Placement," Journal of Advertising, 39(1), Spring, 83-96.

24. Gupta, Pola, Balasubramanian, Siva, and Klassen, Michael (2000), "Viewers' Evaluation of Product Placements in Movies: Public Policy Issues and Managerial Implications," Journal of Current Issues and Research in Advertising, 22(2), 41-52.

25. Gupta, Pola and Gould, Stephen (1997), "Consumers' Perceptions of the Ethics and Acceptability of Product Placement in Movies: Product Categories and Individual Differences," Journal of Current Issues and Research in Advertising, 19(1), 37-50.

26. Gupta, Pola and Lord, Kenneth (1998), "Product Placement in Movies: The Effect of Prominence and Mode on Audience Recall," Journal of Current Issues and Research in Advertising, 20(1), 47-59.

27. Hackley, Chris and Tiwsakul, Rungpaka Amy Hackley nee (2012), "Unpaid Product Placement: The Elephant in the Room in UK TV's New Paid-for Product Placement Market," International Journal of Advertising, 31(4), 703-718.

28. Hang, Haiming (2014), "Brand-Placement Effectiveness and Competitive Interference in Entertainment Media: Brand Recall and Choice in Kids' Video-Game Advertisements," Journal of Advertising Research, June, 192-199.

29. Homburg, Christian, Klarmann, Martin, and Schmitt, Jens (2010), "Brand Awareness in Business Markets: When is it Related to Firm Performance?" International Journal of Research in Marketing, 27, 201-212.

30. Hoyer, W.D. and Brown, S.P. (1990), "Effects of Brand Awareness on Choice for a Common, RepeatPurchase Product," Journal of Consumer Research, 17(2), 141-148.

31. Huang, Rong and Sarigollu, Emine (2012), "How Brand Awareness Relates to Market Outcome, Brand Equity, and the Marketing Mix," Journal of Business Research, 65, 92-99.

32. Janiszewski, Chris, Noel, Hayden, and Sawyer, Alan (2003), "A Meta-analysis of the Spacing Effect in Verbal Learning: Implications for Research on Advertising Repetition and Consumer Memory," Journal of Consumer Research, 30, June, 138-149.

33. Johnson, R. and Kellaris, J. (1988), “An Exploratory Study of Price/Perceived Quality Relationships among Consumer Services," in Houston, M. (Ed.), Advances in Consumer Research, 15, 316-22.

34. Johnstone, Emma and Dodd, Christopher (2000), "Placements as Mediators of Brand Salience within a UK Cinema Audience," Journal of Marketing Communications, 6, 141-158.

35. Karniouchina, Ekaterina V., Uslay, Can, and Erenburg, Grigori (2011), "Do Marketing Media Have Life Cycles? The Case of Product Placement in Movies," Journal of Marketing, 75, May, 28-48.

36. Karrh, James (1998), "Brand Placement: A Review," Journal of Current Issues and Research in Advertising, 20(2), 31-49.

37. Karrh, James, McKee, Kathy, and Pardun, Carol (2003), "Practitioners' Evolving Views on Product Placement Effectiveness," Journal of Advertising Research, 43(2), 138-149.

38. Keller, Kevin (2008), Strategic Brand Management - Building, Measuring, and Managing Brand Equity, $3^{\text {rd }}$ edition. Upper Saddle River, NJ: Prentice Hall.

39. Khan, Imran, Ghauri, Tauqir Ahmad, and Majeed, Salman (2012), "Impact of Brand Related Attributes on Purchase Intention of Customer: A Study about the Customers of Punjab, Pakistan," Interdisciplinary Journal of Contemporary Research in Business, 4(3), July, 194-200. 
40. LaReau, Jamie (2005), "Lexus asks Mags: Use out Cars in articles". Automotive News, Vol. 79, Issue 6158.

41. Laroche, Michel, Kim, Chankon, and Zhou, Lianxi (1996), "Brand Familiarity and Confidence as Determinants of Purchase Intention: An Empirical Test in a Multiple Brand Context," Journal of Business Research, 37, 115-120.

42. Lawrence, R. (1989), "Television: The Battle for Attention," Marketing and Media Decisions, 24(2), 8084.

43. Lee, A. Y. and Sternthal, B. (1999), "The Effects of Positive Mood on Memory," Journal of Consumer Research, 26, 115-127.

44. Mack, Ann (2004), “Ad-justment”. Adweek, 9/20/2004, Vol. 45, Issue 35.

45. Markin, Rom (1979), Marketing. New York, NY: John Wiley \& Sons. In:

46. Mowen, John; Minor, Michael (2000), Consumer Behavior: A Framework, Upper Saddle River, NJ: Prentice Hall.

47. Negunadi, P. (1990), "Recall and Consumer Consideration Sets: Influencing Choice without Altering Brand Evaluations," Journal of Consumer Research, 17, 263-276.

48. Nelson, Michelle R. and Deshpande, Sameer (2013), "The Prevalence of and Consumer Response to Foreign and Domestic Brand Placement in Bollywood Movies," Journal of Advertising, 42(1), 1-15.

49. Noguti, Valeria and Russell, Cristel Antonia (2014), "Normative Influences on Product Placement Effects: Alcohol Brands in Television Series and the Influence of Presumed Influence," Journal of Advertising, 43(1), 46-62.

50. Olney, Thomas, Holbrook, Morris, and Batra, Rajeev (1991), "Consumer Reponses to Advertising: The Effects of Ad Content, Emotions, and Attitude toward the Ad on Viewing Time," Journal of ConsumerResearch, 17(4), 440-453.

51. Phelps, Joseph and Thorson, Eather (1991), "Brand Familiarity and Product Involvement Effects on the Attitude toward an Ad-Brand Attitude Relationship," Advances in Consumer Research, 18, 202-209.

52. Porter, M. E. (1974), "Consumer behavior, Retailer Power and Market Performance in Consumer Goods Industries," The Review of Economics and Statistics, 56(4), 419-436.

53. Russell, Christel Antonia (2002), "Investigating the Effectiveness of Product Placements in Television Shows: The Role of Modality and Plot Connection Congruence on Brand Memory and Attitude," Journal of Consumer Research, 29(3), December, 306-318.

54. Schneider, Lars-Peter and Cornwell, Bettina (2005), "Cashing in on Crashes via Brand Placement in Computer Games - The Effects of Experience and Flow on Memory". International Journal of Advertising, 24(3), 321-343.

55. Schudson, Michael (1984), Advertising, the Uneasy Persuasion, New York: Basic Books Inc.

56. Shah, Syed Saad Hussain, Aziz, Jabran, Jaffari, Ahsan raza, Waris, Sidra, and Ejaz, Wasiq (2012), "The Impact of Brands on Consumer Purchase Intentions," Asian Journal of Business Management, 4(2), 105110 .

57. Singh, Surendra, Mishra, Sanjay, Bendapudi, Neeli, and Linville, Denise (1994), "Enhancing Memory of Television Commercials through Message Spacing," Journal of Marketing Research, 31, August, 384-393.

58. Spiegel Online (2005), "Schleichwerbung - 'Pastewka' unter Verdacht". Retrieved September $23^{\text {rd }}$, from http://www.spiegel.de/kultur/gesellschaft/0,1518,376249,00.html.

59. Spiegel Online (2004), "Product Placement - Hollywoods Blecherne Helden". Retrieved September $20^{\text {th }}$, from http://www.spiegel.de/auto/aktuell/0,1518,303380,00.html.

60. Srivastava, Mala and Kamdar, Rutu Mody (2009), "Brand Image Formation as a Function of Involvement and Familiarity," Paradigm, 13(1), January - June, 84-90.

61. Stammerjohan, Clarie, Wood, Charles M., Chang, Yuhmin, and Thorson, Esther (2005), "An Empirical Investigation of the Interaction Between Publicity, Advertising, and Previous Brand Attitudes and Knowledge," Journal of Advertising, 34(4), Winter, 55-67.

62. Steortz, Eva (1987), "The Cost Efficiency and Communication Effects Associated with Brand Name Exposure within Motion Pictures," unpublished master's thesis, West Virginia University.

63. Stewart-Allen, Allyson (1999), "Product Placement Helps Sell Brands," Marketing News, 33(4), February 15, p.8.

64. Tam, Jackie L.M. (2008), "Brand Familiarity: Its Effects on Satisfaction Evaluations," Journal of Services Marketing, 22(1), 3-12.

65. Taylor, Steven A. and Baker, Thomas L. (1994), “An Assessment of the Relationship Between Service 
Quality and Customer Satisfaction in the Formation of Consumer's Purchase Intentions," Journal of Retailing, 70(2), 163-178.

66. Wiles, Michael A. and Danielova, Anna (2009), "The Worth of Product Placement in Successful Films: An Event Study Analysis," Journal of Marketing, 73, July, 44-63.

67. Wyer Jr., Robert and Srull, Thomas (1989), "Person Memory and Judgment," Psychological Review, 96(1), 58-83.

68. Zazza, Frank (2002), "Product Placement Valuation \& Product Placement News." Retrieved September $22^{\text {nd }}$, from http://www.itvx.com/SpecialReport.asp. 